\title{
The Extent of Commitment of Saudis During Holy Ramadan to Social Distancing Measures Required for the Prevention of Transmission of COVID-19
}

\author{
Nouf Alotaibi ${ }^{1}$ D $\cdot$ Sattam Almutairi ${ }^{2} \cdot$ Moawad Alotaibi $^{3} \cdot$ Mishal M. Alotaibi $^{3} \cdot$ Tahani Alsufian $^{4}$
}

Accepted: 10 October 2020 / Published online: 17 October 2020

(c) Springer Science+Business Media, LLC, part of Springer Nature 2020

\begin{abstract}
Coronavirus disease (hereafter COVID-19) was declared a pandemic by the World Health Organization (WHO) in March 2020. People were admitted to hospitals complaining of fever, fatigue, cough, and difficulty breathing. Consequently, the strategy being adopted to limit the spread of COVID-19 is to encourage people in society to follow preventive measures. We aimed to estimate how the knowledge of and compliance with safe distancing measures affected the progression of the COVID-19 pandemic in Saudi Arabia during Holy Ramadan. A cross-sectional survey was implemented in the central regions of Saudi Arabia from 24th of April to 22nd May to coincide with Ramadan. The study was conducted using a Google forum distributed through social media. Participants were recruited through convenience sampling of the Saudi population. In total, 1515 participants completed the survey. A significant difference between males and females was observed in answering questions about committing to: not attending gatherings, keeping a safe distance, not making physical contact, and staying at home during partial lockdown. In general, participants in our study demonstrated excellent adherence to all social distance measures, considered essential for limiting the spread and progression of COVID-19. However, attitudes regarding reduced physical contact was poor in the Makkah region, which necessitates greater efforts to educate and inform people about the associated risks.
\end{abstract}

Keywords COVID-19 · Saudi · Ramadhan · Pandemic $\cdot$ Social distance

Nouf Alotaibi

nealotaibi@uqu.edu.sa

Sattam Almutairi

b-m23@hotmail.com

Moawad Alotaibi

me.alotaibi@psmmc.med.sa

Mishal M. Alotaibi

Mmiteb@psmmc.med.sa

Tahani Alsufian

ph.tahani2010@hotmail.com

1 Clinical Pharmacy Department, College of Pharmacy, Umm Al Qura University, Mecca, Saudi Arabia

2 Administration Pharmacy, Maternity and Children Hospital, Mecca, Saudi Arabia

3 Family Medicine, Prince Sultan Military Medical City, Riyadh, Saudi Arabia

4 Quality Pharmacy, King Abdul-Aziz Medical City, Riyadh, Saudi Arabia

\section{Introduction}

Coronavirus disease (COVID-19) was declared a pandemic by the World Health Organization (WHO) on March 11, 2020 [1]. The newly discovered virus first emerged in Wuhan City, in the Hubei Province of China at the end of December, 2019 [2, 3]. People in Wuhan were being admitted to hospitals, complaining of fever, fatigue, cough, and difficulty breathing. Furthermore, the symptoms of the illness ranged from mild to severe, in certain cases leading to respiratory failure and death [2-6]. The main features were identified as a severe acute respiratory syndrome $[1,3,5,6]$. The number of people infected in Wuhan increased tremendously [7], and the outbreak of the virus has continued to spread around the world with people from many countries suffering the loss of loved ones and challenging financial circumstances $[6,8,9]$. People identified with high potential risk factors for severe COVID-19 are the elderly, those with chronic lung disease, cardiovascular disease, diabetes mellitus, people who are immunocompromised, and pregnant women $[7,8,10]$. 
Symptoms have been observed to appear in people 1 week following exposure to the disease who then become infected [11]. To date, there is no therapeutic cure for COVID-19 and no vaccine to prevent infection $[5,6,12]$. The National Institutes of Health are currently working to develop a vaccine [10]. In late January 2020, it was confirmed that this infection could transmit from person to person, especially when there has been close contact with infected individuals within 14 days of the onset of symptoms [5, 10, 13, 14]. In addition, it has been established that infection can transfer from a person carrying the virus without demonstrating signs or symptoms of infection (asymptomatic) [15].

To limit the spread of COVID-19 infection, the strategy being adopted is to encourage people to follow preventive measures, which include observing proper hand hygiene (every 15-20 min), refraining from hands shakes, maintaining social distancing, avoiding crowded places, and observing quarantine protocols. Furthermore, closing public places such as schools, restaurants, barbershops, and workplaces whilst letting people work remotely from home have also been introduced to reduce the spread of the virus $[2,9,12$, $13,16,17]$.

On March 2, the Saudi Ministry of Health (MOH) announced the country's first case of COVID-19. As part of an awareness campaign to prevent its spread [18], Saudi authorities announced a lockdown in mid-March 2020, banning people from all gatherings (such as gyms, malls, funerals, weddings, and other social events). This was followed by the closure of cinema theatres, coffee shops, and restaurants.

In this study, we surveyed a sample drawn from Saudi society, asking several questions to determine the extent of their commitment to social distancing measures, such as not attending gatherings outside their homes, maintaining a safe distance from others, having no physical contact (such as handshaking and hugging), not having meals with others, and staying home during partial lockdown. We aimed to determine how knowledge of and compliance with safe distancing measures would affect the progression of COVID-19 in Saudi Arabia during Holy Ramadan.

\section{Methods}

A descriptive, cross-sectional, survey was conducted from 24th of April to 22nd May (Ramadan: 9th month of the Islamic calendar), as many gatherings usually occur during this month. The survey commenced from five mean points concurrently (Riyadh, Makkah, Almadinah, Jeddah, and others) randomly representing the central regions of Saudi Arabia. The survey was disseminated through links on social networking sites. We surveyed a convenience sample of participants drawn from the Saudi population.
Survey questions were developed in Arabic, the native language of Saudi Arabia; however, questions were also available in English language. The survey addressed socio-demographic characteristics of the participants and their knowledge regarding social distancing measures during the COVID-19 outbreak.

First, a survey was developed based on reviews of social distancing recommendations issued by the Saudi $\mathrm{MOH}$ and the World Health Organization (WHO). Second, a draft of the study survey was revised by three academic specialists who reviewed it for any recommendations or modifications. Questions about social distancing were then revised according to the feedback.

The next step was to conduct a pilot study that was intended to test the questionnaire with 20 participants who were later eliminated from the overall sample. The initial pilot phase was conducted before the distribution of the main survey to assess the reliability and validity of the questionnaire. The data were used to assess the internal consistency (reliability) using Cronbach's alpha. The outcomes showed acceptable internal reliability (Cronbach's alpha $=0.82$ ).

An online Google form was generated, and participants were asked to fill out and submit the survey.

The sample size was determined using the Cochran's sample size formula as follows: $\mathrm{n} 0=\mathrm{Z} 2 \mathrm{pq} / \mathrm{e} 2$. Because there have been no similar studies related to coronavirus disease, the calculations were based on an assumption that the probability of having good knowledge of COVID-19 social distancing guidance was 50\% [19] at a 99\% confidence interval, with Z2 as the square of confidence level at $99 \%$ from the normal table (2.575), and a margin of error of 3.31. The required sample size was calculated to be 1513 participants, and we recruited 1515 participants. The survey portal was then closed.

Descriptive statistics were used to summarise sociodemographic characteristics of the data and the responses to questions concerning knowledge about social distancing guidance. The data were summarised as frequencies (n) and percentages (\%) for the categorical variables. A chi square test was used where appropriate. All data analyses were performed using Statistical Package for the Social Sciences (SPSS) software, version 26. A value of $\mathrm{P}<0.05$ was considered statistically significant.

This study was approved by the Ethics Committee of Umm Al-Qura University. Respondents' concealment and confidentiality were ensured. Submission of a completed questionnaire was considered consent to participate in the study.

\section{Results}

In total, 1515 participants completed the survey. Table 1 presents the demographic data for participants, of whom $403(26.6 \%)$ were male and $1112(73.4 \%)$ were female. In 
terms of age, the largest proportion of participants was from the age group $19-40$ years $(n=1287 ; 85 \%)$, while only 2 participants $(0.1 \%)$ were aged older than 65 years. With regard to educational level, 1090 participants (71.9\%) had a bachelor's degree, while only $31(2 \%)$ had a Ph.D. Most participants were from Riyadh $(n=632 ; 41.7 \%)$ and $334(22 \%)$ were health workers, while 1181 (78\%) participants were not health providers.

Table 2 demonstrates the frequencies and rates of responses for the survey questions. It was evident from participant responses that the majority were highly committed to all social distancing measures presented in the survey.

Table 3 illustrates differences in answers based on gender. A significant difference was observed between males and females when asked about committing to: not attending gatherings, keeping a safe distance, not making physical contact, and staying home during partial lockdown $(\mathrm{p}=<0.001$, $\mathrm{p}=<0.001, \mathrm{p}=0.002$, and $\mathrm{p}=<0.001$, respectively).

A demonstration of differences in responses based on age group are presented in Table 4 . There was no observed significant differences between age groups for any of the questions.

Table 5 displays differences in answers based on educational level, indicating whether a significant difference between groups could be observed. A significant difference was observed when asked about commitment to: not

Table 1 Demographic profile of the participants $(\mathrm{N}=1515)$

\begin{tabular}{lll}
\hline Demographic characteristics & $n$ & $\%$ \\
\hline Gender & & \\
Male & 403 & 26.6 \\
Female & 1112 & 73.4 \\
Age & & \\
19-40 & 1287 & 85 \\
$41-65$ & 198 & 13.1 \\
18 and younger & 28 & 1.8 \\
Older than 65 & 2 & 0.1 \\
Educational level & & \\
High school & 243 & 16 \\
Bachelor's & 1090 & 71.9 \\
Masters & 151 & 10 \\
Ph.D. & 31 & 2 \\
City & & \\
Riyadh & 632 & 41.7 \\
Jeddah & 157 & 10.4 \\
Makkah & 249 & 16.4 \\
Madinah & 43 & 2.8 \\
Other & 434 & 28.6 \\
Health worker & & \\
Yes & 334 & 22 \\
No & 1181 & 78 \\
\hline
\end{tabular}

attend gatherings $(\mathrm{p}=0.002)$, not having meals with others $(\mathrm{p}=0.035)$, and staying at home during partial lockdown $(\mathrm{p}=0.005)$.

Table 6 presents differences in answers of based on the city in which participants are living. A significant difference was evident when asked about a commitment to: keeping a safe distance, not making physical contact, and staying at home during partial lockdown, $(\mathrm{p}=<0.014, \mathrm{p}=<0.001$, and $\mathrm{p}=<0.049$, respectively).

Table 7 demonstrates differences between health workers and non-health workers. A significant difference was only observed when answering about commitment to not making physical contact $(\mathrm{p}=0.001)$.

\section{Discussion}

The novel coronavirus disease COVID-19 was first identified during the outbreak of severe acute respiratory syndrome in Wuhan, China, in December 2019 [2, 20]. To date, more than 34 million people have been infected with COVID-19, with mortality of more than 1 million cases [21]. The first identified case in Saudi Arabia was on March 2, and by the end of May more than 85,000 cases had been identified with 503 deaths [22].

Saudi Arabia is the biggest country in the Gulf region, with a population of more than 34 million people [23]. Ramadan is the month during which the community reconnects with family, friends, and neighbours, showing appreciation and bonding together for a common spiritual cause.

Ramadan's holy month is a distinct social and religious gathering where Muslims families and friends around the world unite to break their fast together in the evening at sundown (iftar) or before sunrise during (suhour). Many Muslims increase their attendance at mosques during the month and assemble for extended prayers (Taraweeh and qiyam). Some Muslims also spend days and nights at mosques for prayers, especially during the last days of Ramadan (i'tikaf). These spiritual practices are frequently observed throughout the month. This year, Ramadan falls between the 24th of April and the 23rd of May, just as the COVID-19 pandemic continues.

Transmission of COVID-19 occurs through contact between people as the virus is spread via respiratory droplets and contact with surface contaminants. To reduce the effect on public health, many countries have employed physical distancing actions intended to interrupt virus transmission by mitigating interaction between people. These measures present essential mechanisms to control the spread of infection, particularly respiratory infections, associated with large gatherings of people.

These distancing measures (including but not limited to the closure of mosques) prohibit public congregations and 
Table 2 Participants answers to survey questions $(\mathrm{N}=1515)$

\begin{tabular}{|c|c|c|}
\hline Question & $n$ & $\%$ \\
\hline \multicolumn{3}{|c|}{ Q1/How much are you committed to the social distancing measure of not attending gatherings out of home? } \\
\hline Always & 1127 & 74.40 \\
\hline Often & 334 & 22.00 \\
\hline Sometimes & 46 & 3.00 \\
\hline Never & 8 & 0.50 \\
\hline \multicolumn{3}{|c|}{ Q2/How much are you committed to the social distancing measure of maintaining a safe distance from other people? } \\
\hline Always & 981 & 64.80 \\
\hline Often & 368 & 24.30 \\
\hline Sometimes & 116 & 7.70 \\
\hline Never & 50 & 3.30 \\
\hline \multicolumn{3}{|c|}{ Q3/How much are you committed to the social distancing measure of no physical contact (like hand shaking, hugging)? } \\
\hline Always & 1087 & 71.70 \\
\hline Often & 268 & 17.70 \\
\hline Sometimes & 106 & 7.00 \\
\hline Never & 54 & 3.60 \\
\hline \multicolumn{3}{|c|}{ Q4/How much are you committed to the social distancing measure of not having meals with others? } \\
\hline Always & 1296 & 85.50 \\
\hline Often & 125 & 8.30 \\
\hline Sometimes & 52 & 3.40 \\
\hline Never & 42 & 2.80 \\
\hline \multicolumn{3}{|c|}{ Q5/How much are you committed to the social distancing measure of staying at home during partial lockdown? } \\
\hline Always & 1263 & 83.40 \\
\hline Often & 207 & 13.70 \\
\hline Sometimes & 33 & 2.20 \\
\hline Never & 12 & 0.80 \\
\hline
\end{tabular}

other limits on movement and will have direct consequences for the social and spiritual gatherings fundamental to Ramadan $[24,25]$. In this paper, we present the results of our survey about the knowledge and adherence to social distancing during Holy Ramadan.

In our study, participants showed a generally positive attitude towards social distance measures, as almost three quarters of participants said they would never attend gatherings out of home after the lockdown, while $22 \%$ said they often stayed home, $3 \%$ said they would sometimes stay home, while just $0.5 \%$ took no precautionary measures. Approximately two thirds (64\%) of participant maintained a safe distance from people, while almost $4 \%$ never take this precaution. More than $70 \%$ of our study population said they avoided handshaking and hugging during the virus outbreak period, while almost $4 \%$ did not avoid physical contact during the same period. Moreover, $85 \%$ of participants did not share meals with others, while almost $3 \%$ said they gathered and shared meals without any precautions. Regarding the partial lockdown, only $0.8 \%(n=12)$ of participants said they left their homes, which may indicate negligence concerning the importance of these precautions in limiting the viral outbreak.

\section{Knowledge of Social Distancing Measures Regarding Not Attending Gatherings Out of Home}

In general, participants in our study were highly committed to all the social distancing measures, especially abstaining from gatherings out of home. Females were more committed to staying at home than males, as were people aged 41-64 years (92.8\%) and people older than 65 years (100\%), which may be because of a heightened risk of age-associated chronic diseases making them more likely to suffer severely from coronavirus, which increases the risk of corona-related morbidity and mortality - proven from multiple studies published about the disease in China [8, 9, 26, 27].

There were no differences identified between the educational level of the participants, region, and healthcare worker status regarding staying at home.

\section{Knowledge of Social Distancing Measures Regarding Maintaining a Safe Distance from Other People}

Participants aged 41 years and over were committed to maintaining a safe distance with other people (75\%); however, 
Table 3 Gender-based comparison of answers $(\mathrm{N}=1515)$

\begin{tabular}{|c|c|c|c|c|c|c|}
\hline \multirow[b]{2}{*}{ Answer } & \multicolumn{2}{|c|}{ Male $(n=403)$} & \multicolumn{2}{|c|}{ Female $(n=1112)$} & \multirow[b]{2}{*}{ Chi-square } & \multirow[b]{2}{*}{ P-value } \\
\hline & $n$ & $\%$ & $n$ & $\%$ & & \\
\hline \multicolumn{7}{|c|}{$\begin{array}{l}\text { Q1/How much are you committed to the social distancing measure of not attending gatherings out of } \\
\text { home? }\end{array}$} \\
\hline Always & 261 & 64.76 & 866 & 77.88 & 32.168 & $<0.001 *$ \\
\hline Often & 125 & 31.02 & 209 & 18.79 & & \\
\hline Sometimes & 12 & 2.98 & 34 & 3.06 & & \\
\hline Never & 5 & 1.24 & 3 & 0.27 & & \\
\hline \multicolumn{7}{|c|}{$\begin{array}{l}\text { Q2/How much are you committed to the social distancing measure of maintaining a safe distance from } \\
\text { other people? }\end{array}$} \\
\hline Always & 210 & 52.11 & 771 & 69.33 & 48.877 & $<0.001^{*}$ \\
\hline Often & 148 & 36.72 & 220 & 19.78 & & \\
\hline Sometimes & 33 & 8.19 & 83 & 7.46 & & \\
\hline Never & 12 & 2.98 & 38 & 3.42 & & \\
\hline \multicolumn{7}{|c|}{$\begin{array}{l}\text { Q3/How much are you committed to the social distancing measure of no physical contact (like hand } \\
\text { shaking, hugging)? }\end{array}$} \\
\hline Always & 315 & 78.16 & 772 & 69.42 & 15.345 & $0.002 *$ \\
\hline Often & 61 & 15.14 & 207 & 18.62 & & \\
\hline Sometimes & 22 & 5.46 & 84 & 7.55 & & \\
\hline Never & 5 & 1.24 & 49 & 4.41 & & \\
\hline \multicolumn{7}{|c|}{ Q4/How much are you committed to the social distancing measure of not having meals with others? } \\
\hline Always & 331 & 82.13 & 965 & 86.78 & 5.170 & 0.160 \\
\hline Often & 41 & 10.17 & 84 & 7.55 & & \\
\hline Sometimes & 17 & 4.22 & 35 & 3.15 & & \\
\hline Never & 14 & 3.47 & 28 & 2.52 & & \\
\hline \multicolumn{7}{|c|}{$\begin{array}{l}\text { Q5/How much are you committed to the social distancing measure of staying at home during partial } \\
\text { lockdown? }\end{array}$} \\
\hline Always & 299 & 74.19 & 964 & 86.69 & 48.877 & $<0.001 *$ \\
\hline Often & 77 & 19.11 & 130 & 11.69 & & \\
\hline Sometimes & 18 & 4.47 & 15 & 1.35 & & \\
\hline Never & 9 & 2.23 & 3 & 0.27 & & \\
\hline
\end{tabular}

*Significant at level 0.05

this reduced to almost $60 \%$ for those younger than 40 years. Regarding educational level, participants with a Ph.D. degree were more aware of and adhered to safe distancing guidelines.

Interestingly, only $61 \%$ of healthcare workers have been maintaining a safe distance measure compared to $65 \%$ of non-healthcare workers.

There is no difference in terms of knowledge of and adherence to safe distancing in different regions of Saudi Arabia, all of which showed almost $65 \%$ of participants.

\section{Knowledge of Social Distancing Measures Regarding Maintaining No Physical Contact (Like Handshaking, Hugging)}

More than three-quarters of male participants (78\%) maintain no physical contact, while a lower proportion was observed among females (69\%). Participants less than 40 years old demonstrated good knowledge and attitude toward physical contact, with almost $80 \%$ having no physical contact at all.

In Makkah province, only $48 \%$ committed to no physical contact, which could account for the higher number of COVID-19 cases witnessed in Makkah.

More than $80 \%$ of healthcare workers committed to no physical contact.

\section{Knowledge of Social Distancing Measures Regarding Not Having Meals with Others and Staying at Home During Partial Lockdown}

In general, all participants in our study were committed to and aware of not having meals with others with no differences evident regarding gender, educational level, region, healthcare worker status, and age group.

Females generally committed more to staying at home, or during allowed time of the partial lockdown. 
Table 4 Age group-based comparison of answers $(\mathrm{N}=1515)$

\begin{tabular}{|c|c|c|c|c|c|c|}
\hline & $\begin{array}{l}18 \text { and younger } \\
(n=1287)\end{array}$ & $\begin{array}{l}19-40 \\
(n=198)\end{array}$ & $\begin{array}{l}41-65 \\
(n=28)\end{array}$ & $\begin{array}{l}\text { Older than } 65 \\
(n=2)\end{array}$ & & \\
\hline Answer & $\%$ & $\%$ & $\%$ & $\%$ & Chi-square & P-value \\
\hline
\end{tabular}

Q1/How much are you committed to the social distancing measure of not attending gatherings out of home?

$\begin{array}{llrlrrrrrrr}\text { Always } & 942 & 73.19 & 157 & 79.29 & 26 & 92.86 & 2 & 100.00 & 16.461 & 0.058 \\ \text { Often } & 298 & 23.15 & 35 & 17.68 & 1 & 3.57 & 0 & 0.00 & & \\ \text { Sometimes } & 40 & 3.11 & 6 & 3.03 & 0 & 0.00 & 0 & 0.00 & & \\ \text { Never } & 7 & 0.54 & 0 & 0.00 & 1 & 3.57 & 0 & 0.00 & \end{array}$

Q2/How much are you committed to the social distancing measure of maintaining a safe distance from other people?

$\begin{array}{llrlrlrrrrr}\text { Always } & 833 & 64.72 & 125 & 63.13 & 21 & 75.00 & 2 & 100.00 & 6.273 & 0.712 \\ \text { Often } & 313 & 24.32 & 51 & 25.76 & 4 & 14.29 & 0 & 0.00 & & \\ \text { Sometimes } & 95 & 7.38 & 19 & 9.60 & 2 & 7.14 & 0 & 0.00 & & \\ \text { Never } & 46 & 3.57 & 3 & 1.52 & 1 & 3.57 & 0 & 0.00 & & \end{array}$

Q3/How much are you committed to the social distancing measure of no physical contact (like hand shaking, hugging)?

$\begin{array}{llrlrlrlrrr}\text { Always } & 910 & 70.71 & 157 & 79.29 & 19 & 67.86 & 1 & 50.00 & 10.838 & 0.287 \\ \text { Often } & 239 & 18.57 & 22 & 11.11 & 6 & 21.43 & 1 & 50.00 & & \\ \text { Sometimes } & 90 & 6.99 & 13 & 6.57 & 3 & 10.71 & 0 & 0.00 & & \\ \text { Never } & 48 & 3.73 & 6 & 3.03 & 0 & 0.00 & 0 & 0.00 & \end{array}$

Q4/How much are you committed to the social distancing measure of not having meals with others?

$\begin{array}{llrlrlrrrrr}\text { Always } & 1089 & 84.62 & 179 & 90.40 & 26 & 92.86 & 2 & 100.00 & 9.097 & 0.428 \\ \text { Often } & 111 & 8.62 & 14 & 7.07 & 0 & 0.00 & 0 & 0.00 & & \\ \text { Sometimes } & 48 & 3.73 & 3 & 1.52 & 1 & 3.57 & 0 & 0.00 & & \\ \text { Never } & 39 & 3.03 & 2 & 1.01 & 1 & 3.57 & 0 & 0.00 & & \end{array}$

Q5/How much are you committed to the social distancing measure of staying at home during partial lockdown?

\begin{tabular}{llrlrrrrrrr} 
Always & 1072 & 83.29 & 164 & 82.83 & 26 & 92.86 & 1 & 50.00 & 6.414 & 0.698 \\
Often & 175 & 13.60 & 29 & 14.65 & 2 & 7.14 & 1 & 50.00 & & \\
Sometimes & 28 & 2.18 & 5 & 2.53 & 0 & 0.00 & 0 & 0.00 & & \\
Never & 12 & 0.93 & 0 & 0.00 & 0 & 0.00 & 0 & 0.00 & & \\
\hline
\end{tabular}

*Significant at level 0.05

\section{Conclusion}

In general, participants in our study demonstrated excellent adherence to all social distancing measures, which is essential to limit the spread and progression of COVID-19. However, attitudes regarding physical contact was low in the Makkah region, which necessitates greater effort in educating and warning people about the risks. 
Table 5 Education level comparison of answers $(\mathrm{N}=1515)$

\begin{tabular}{|c|c|c|c|c|c|c|c|}
\hline \multirow[b]{2}{*}{ Answer } & $\begin{array}{l}\text { High school } \\
(n=243)\end{array}$ & $\begin{array}{l}\text { Bachelor's } \\
(n=1090)\end{array}$ & $\begin{array}{l}\text { Masters } \\
(n=151)\end{array}$ & \multicolumn{2}{|c|}{$\begin{array}{l}\text { Ph.D } \\
(n=31)\end{array}$} & \multirow[b]{2}{*}{ Chi-square } & \multirow[b]{2}{*}{ P-value } \\
\hline & $\%$ & $\%$ & $n$ & $n$ & $\%$ & & \\
\hline
\end{tabular}

Q1/How much are you committed to the social distancing measure of not attending gatherings out of home?

$\begin{array}{llrlrlrlrrr}\text { Always } & 203 & 83.54 & 803 & 73.67 & 98 & 64.90 & 23 & 74.19 & 25.713 & 0.002 * \\ \text { Often } & 31 & 12.76 & 253 & 23.21 & 42 & 27.81 & 8 & 25.81 & & \\ \text { Sometimes } & 7 & 2.88 & 30 & 2.75 & 9 & 5.96 & 0 & 0.00 & & \\ \text { Never } & 2 & 0.82 & 4 & 0.37 & 2 & 1.32 & 0 & 0.00 & \end{array}$

Q2/How much are you committed to the social distancing measure of maintaining a safe distance from other people?

$\begin{array}{llrrrrrrrrr}\text { Always } & 161 & 66.26 & 710 & 65.14 & 86 & 56.95 & 24 & 77.42 & 7.869 & 0.547 \\ \text { Often } & 56 & 23.05 & 261 & 23.94 & 45 & 29.80 & 6 & 19.35 & & \\ \text { Sometimes } & 19 & 7.82 & 81 & 7.43 & 15 & 9.93 & 1 & 3.23 & & \\ \text { Never } & 7 & 2.88 & 38 & 3.49 & 5 & 3.31 & 0 & 0.00 & & \end{array}$

Q3/How much are you committed to the social distancing measure of no physical contact (like hand shaking, hugging)?

$\begin{array}{llrrrrrrrrr}\text { Always } & 193 & 79.42 & 759 & 69.63 & 108 & 71.52 & 27 & 87.10 & 15.177 & 0.086 \\ \text { Often } & 32 & 13.17 & 203 & 18.62 & 29 & 19.21 & 4 & 12.90 & & \\ \text { Sometimes } & 11 & 4.53 & 85 & 7.80 & 10 & 6.62 & 0 & 0.00 & & \\ \text { Never } & 7 & 2.88 & 43 & 3.94 & 4 & 2.65 & 0 & 0.00 & & \end{array}$

Q4/How much are you committed to the social distancing measure of not having meals with others?

$\begin{array}{llrrrrrrrrr}\text { Always } & 218 & 89.71 & 931 & 85.41 & 119 & 78.81 & 28 & 90.32 & 18.001 & 0.035^{*} \\ \text { Often } & 14 & 5.76 & 85 & 7.80 & 24 & 15.89 & 2 & 6.45 & & \\ \text { Sometimes } & 6 & 2.47 & 42 & 3.85 & 3 & 1.99 & 1 & 3.23 & & \\ \text { Never } & 5 & 2.06 & 32 & 2.94 & 5 & 3.31 & 0 & 0.00 & \end{array}$

Q5/How much are you committed to the social distancing measure of staying at home during partial lockdown?

\begin{tabular}{llrlrlrlrrr} 
Always & 217 & 89.30 & 909 & 83.39 & 117 & 77.48 & 20 & 64.52 & 23.532 & $0.005^{*}$ \\
Often & 20 & 8.23 & 150 & 13.76 & 28 & 18.54 & 9 & 29.03 & & \\
Sometimes & 6 & 2.47 & 23 & 2.11 & 3 & 1.99 & 1 & 3.23 & & \\
Never & 0 & 0.00 & 8 & 0.73 & 3 & 1.99 & 1 & 3.23 & & \\
\hline
\end{tabular}

*Significant at level 0.05 
Table 6 City-based comparison of answers $(\mathrm{N}=1515)$

\begin{tabular}{|c|c|c|c|c|c|c|c|c|c|c|c|c|}
\hline \multirow[b]{2}{*}{ Answer } & \multicolumn{2}{|c|}{$\begin{array}{l}\text { Riyadh } \\
(n=632)\end{array}$} & \multicolumn{2}{|c|}{$\begin{array}{l}\text { Jeddah } \\
(n=157)\end{array}$} & \multicolumn{2}{|c|}{$\begin{array}{l}\text { Makkah } \\
(n=249)\end{array}$} & \multicolumn{2}{|c|}{$\begin{array}{l}\text { Madinah } \\
(n=43)\end{array}$} & \multicolumn{2}{|c|}{$\begin{array}{l}\text { Other } \\
(n=434)\end{array}$} & \multirow[b]{2}{*}{ Chi-square } & \multirow[t]{2}{*}{ P-value } \\
\hline & $n$ & $\%$ & $n$ & $\%$ & $n$ & $\%$ & $n$ & $\%$ & $n$ & $\%$ & & \\
\hline \multicolumn{13}{|c|}{ Q1/How much are you committed to the social distancing measure of not attending gatherings out of home? } \\
\hline Always & 473 & 74.84 & 120 & 76.43 & 193 & 77.51 & 33 & 76.74 & 308.00 & 70.97 & 17.263 & 0.140 \\
\hline Often & 134 & 21.20 & 35 & 22.29 & 52 & 20.88 & 9 & 20.93 & 104.00 & 23.96 & & \\
\hline Sometimes & 24 & 3.80 & 2 & 1.27 & 3 & 1.20 & 1 & 2.33 & 16 & 3.69 & & \\
\hline Never & 1 & 0.16 & 0 & 0.00 & 1 & 0.40 & 0 & 0.00 & 6 & 1.38 & & \\
\hline \multicolumn{13}{|c|}{ Q2/How much are you committed to the social distancing measure of maintaining a safe distance from other people? } \\
\hline Always & 399 & 63.13 & 108 & 68.79 & 159 & 63.86 & 29 & 67.44 & 286.00 & 65.90 & 25.072 & $0.014 *$ \\
\hline Often & 150 & 23.73 & 44 & 28.03 & 72 & 28.92 & 10 & 23.26 & 92.00 & 21.20 & & \\
\hline Sometimes & 58 & 9.18 & 3 & 1.91 & 16 & 6.43 & 2 & 4.65 & 37 & 8.53 & & \\
\hline Never & 25 & 3.96 & 2 & 1.27 & 2 & 0.80 & 2 & 4.65 & 19 & 4.38 & & \\
\hline \multicolumn{13}{|c|}{ Q3/How much are you committed to the social distancing measure of no physical contact (like hand shaking, hugging)? } \\
\hline Always & 434 & 68.67 & 121 & 77.07 & 121 & 48.59 & 29 & 67.44 & 299.00 & 68.89 & 36.999 & $<0.001^{*}$ \\
\hline Often & 120 & 18.99 & 31 & 19.75 & 31 & 12.45 & 7 & 16.28 & 79.00 & 18.20 & & \\
\hline Sometimes & 49 & 7.75 & 3 & 1.91 & 3 & 1.20 & 6 & 13.95 & 34 & 7.83 & & \\
\hline Never & 29 & 4.59 & 2 & 1.27 & 2 & 0.80 & 1 & 2.33 & 22 & 5.07 & & \\
\hline \multicolumn{13}{|c|}{ Q4/How much are you committed to the social distancing measure of not having meals with others? } \\
\hline Always & 544 & 86.08 & 138 & 87.90 & 215 & 86.35 & 35 & 81.40 & 364.00 & 83.87 & 15.402 & 0.220 \\
\hline Often & 55 & 8.70 & 10 & 6.37 & 23 & 9.24 & 5 & 11.63 & 32.00 & 7.37 & & \\
\hline Sometimes & 16 & 2.53 & 7 & 4.46 & 9 & 3.61 & 2 & 4.65 & 18 & 4.15 & & \\
\hline Never & 17 & 2.69 & 2 & 1.27 & 2 & 0.80 & 1 & 2.33 & 20 & 4.61 & & \\
\hline \multicolumn{13}{|c|}{ Q5/How much are you committed to the social distancing measure of staying at home during partial lockdown? } \\
\hline Always & 539 & 85.28 & 126 & 80.25 & 216 & 86.75 & 35 & 81.40 & 347.00 & 79.95 & 21.120 & $0.049 *$ \\
\hline Often & 77 & 12.18 & 27 & 17.20 & 30 & 12.05 & 6 & 13.95 & 67.00 & 15.44 & & \\
\hline Sometimes & 14 & 2.22 & 3 & 1.91 & 3 & 1.20 & 2 & 4.65 & 11 & 2.53 & & \\
\hline Never & 2 & 0.32 & 1 & 0.64 & 0 & 0.00 & 0 & 0.00 & 9 & 2.07 & & \\
\hline
\end{tabular}

*Significant at level 0.05 
Table 7 Health care workers comparison of answers $(\mathrm{N}=1515)$

\begin{tabular}{llllllll}
\hline & \multicolumn{2}{l}{ Yes $(n=334)$} & & \multicolumn{2}{l}{ No $(n=1181)$} & & \\
\cline { 2 - 3 } Answer & $n$ & & $n$ & & Chi-square & P-value \\
\hline $\begin{array}{l}\text { Q1/How much are you committed to the social distancing measure of not attending gatherings out of } \\
\text { home? }\end{array}$ & 248 & 74.25 & & 879 & 74.43 & 3.304 & 0.347 \\
Always & 73 & 21.86 & & 261 & 22.10 & \\
Often & 13 & 3.89 & & 33 & 2.79 & \\
Sometimes & 0 & 0.00 & 8 & 0.68 &
\end{tabular}

Q2/How much are you committed to the social distancing measure of maintaining a safe distance from other people?

$\begin{array}{llrlrrr}\text { Always } & 207 & 61.98 & 774 & 65.54 & 2.629 & 0.452 \\ \text { Often } & 91 & 27.25 & 277 & 23.45 & & \\ \text { Sometimes } & 27 & 8.08 & 89 & 7.54 & \\ \text { Never } & 9 & 2.69 & 41 & 3.47 & \end{array}$

Q3/How much are you committed to the social distancing measure of no physical contact (like hand shaking, hugging)?

$\begin{array}{llrlrrr}\text { Always } & 268 & 80.24 & 819 & 69.35 & 17.560 & 0.001^{*} \\ \text { Often } & 44 & 13.17 & 224 & 18.97 & & \\ \text { Sometimes } & 18 & 5.39 & 88 & 7.45 & \\ \text { Never } & 4 & 1.20 & 50 & 4.23 & \end{array}$

Q4/How much are you committed to the social distancing measure of not having meals with others?

$\begin{array}{llrlrrr}\text { Always } & 281 & 84.13 & 1015 & 85.94 & 7.263 & 0.064 \\ \text { Often } & 34 & 10.18 & 91 & 7.71 & & \\ \text { Sometimes } & 15 & 4.49 & 37 & 3.13 & \\ \text { Never } & 4 & 1.20 & 38 & 3.22 & \end{array}$

Q5/How much are you committed to the social distancing measure of staying at home during partial lockdown?

\begin{tabular}{|c|c|c|c|c|c|c|}
\hline Always & 278 & 83.23 & 985 & 83.40 & 1.484 & 0.686 \\
\hline Often & 48 & 14.37 & 159 & 13.46 & & \\
\hline Sometimes & 7 & 2.10 & 26 & 2.20 & & \\
\hline Never & 1 & 0.30 & 11 & 0.93 & & \\
\hline
\end{tabular}

*Significant at level 0.05

\section{Compliance with Ethical Standards}

Conflict of interest The authors declare that they have no known competing financial interests or personal relationships that could influence the work reported in this paper.

\section{References}

1. Basile, C., Combe, C., Pizzarelli, F., et al. (2020). Recommendations for the prevention, mitigation, and containment of the emerging SARS-CoV-2 (COVID-19) pandemic in hemodialysis centers. Nephrology Dialysis Transplantation, 35(5), 737-741. https://doi. org/10.1093/ndt/gfaa069

2. Singhal, T. (2020). A review of coronavirus disease-2019 (COVID-19). Indian Journal of Pediatrics, 87(4), 281-286. https ://doi.org/10.1007/s12098-020-03263-6

3. Ge, H., Wang, X., Yuan, X., et al. (2020). The epidemiology and clinical information about COVID-19. European Journal of
Clinical Microbiology \& Infectious Diseases: Official Publication of the European Society of Clinical Microbiology, 39(6), 1011-1019. https://doi.org/10.1007/s10096-020-03874-z

4. Lake, M. (2020). What we know so far: COVID-19 current clinical knowledge and research. Clinical Medicine, 20(2), 124-127.

5. Rothan, H., \& Byrareddy, S. (2020). The epidemiology and pathogenesis of coronavirus disease (COVID-19) outbreak. Journal of Autoimmunity, 109, 10-24.

6. Cao, B., Wang, Y., Wen, D., et al. (2020). A trial of lopinavir-ritonavir in adults hospitalized with severe Covid-19. New England Journal of Medicine, 382(19), 1787-1799.

7. Gandhi, R., Lynch, J., \& del Rio, C. (2020). Mild or moderate Covid-19. New England Journal of Medicine, 382(19), 1787-1799.

8. Mehra, M., Desai, S., Kuy, S., Henry, T., \& Patel, A. (2020). Cardiovascular disease, drug therapy, and mortality in Covid-19. New England Journal of Medicine, 382(19), 1787-1799.

9. Chakraborty, I., \& Maity, P. (2020). COVID-19 outbreak: Migration, effects on society, global environment, and prevention. Science of The Total Environment, 728, 13-24.

10. Rasmussen, S., Smulian, J., Lednicky, J., Wen, T., \& Jamieson, D. (2020). Coronavirus disease 2019 (COVID-19) and pregnancy: 
What obstetricians need to know. American Journal of Obstetrics and Gynecology, 222(5), 415-426.

11. Berlin, D., Gulick, R., \& Martinez, F. (2020). Severe Covid19. New England Journal of Medicine. https://doi.org/10.1056/ NEJMcp2009575

12. Güner, R., Hasanoğlu, İ, \& Aktaş, F. (2020). COVID-19: Prevention and control measures in the community. Turkish Journal of Medical Sciences, 50(SI-1), 571-577.

13. Chen, H., Xu, W., Paris, C., Reeson, A., \& Li, X. (2020). Social distance and SARS memory: impact on the public awareness of 2019 novel coronavirus (COVID-19) outbreak. https://doi. org/10.1101/2020.03.11.20033688.

14. Bhatraju, P., Ghassemieh, B., Nichols, M., et al. (2020). Covid-19 in critically ill patients in the Seattle region-Case series. New England Journal of Medicine, 382(21), 2012-2022.

15. Jin, Y., Yang, H., Ji, W., et al. (2020). Virology, epidemiology, pathogenesis, and control of COVID-19. Viruses, 12(4), 372.

16. Prem, K., Liu, Y., Russell, T., et al. (2020). The effect of control strategies that reduce social mixing on outcomes of the COVID-19 epidemic in Wuhan, China. SSRN Electronic Journal, 5, 261-270.

17. Jarvis, C., Van Zandvoort, K., Gimma, A., et al. (2020). Quantifying the impact of physical distance measures on the transmission of COVID-19 in the UK. BMC Medicine, 18(1-5), 2020.

18. Moh, T., (2020). MOH news-MOH issues COVID-19 awareness guidelines in many languages. [Online] Moh.gov.sa. Retrieved May 20, 2020, from https://www.moh.gov.sa/en/Ministry/Media Center/News/Pages/News-2020-03-17-001.aspx.

19. Lemeshow, S., Hosmer, D. W., Klar, J., et al. (1990). World Health Organization. Adequacy of sample size in health studies. Chichester: Wiley. Retrieved May 22, 2020, from https://apps.who.int/ iris/handle/1066541607.

20. Wang, C., Horby, P. W., Hayden, F. G., \& Gao, G. F. (2020). A novel coronavirus outbreak of global health concern. The
Lancet, 395(10223), 470-473. https://doi.org/10.1016/S0140 $-6736(20) 30185-9$

21. WHO. (2020). Coronavirus disease (COVID-19) dashboard. Retrieved October 2, 2020, from Covid19. https://www.who.int/ coronavirus/data.

22. COVID 19 Dashboard: Saudi Arabia. Retrieved May 31, 2020, from https://covid19.moh.gov.sa/.

23. General Authority for Statistics kingdom of Saudi Arabia Website (2019). Retrieved May 21, 2020 from https://www.stats.gov.sa/ar/ indicators $/ 1$.

24. Bakhotmah, B. A. (2011). The puzzle of self-reported weight gain in a month of fasting (Ramadan) among a cohort of Saudi families in Jeddah, Western Saudi Arabia. Nutrition Journal. https://doi. org/10.1186/1475-2891-10-84

25. World Health Organization. (2020). Practical considerations and recommendations for religious leaders and faith-based communities in the context of COVID-19-publication, risk assessment tool, decision tree. Retrieved May 21, 2020, from https://www.who.int/ publications-detail/safe-ramadan-practices-in-the-context-of-thecovid-19-interim-guidance.

26. Groups at Higher Risk for Severe Illness. Retrieved May 26, 2020, from https://www.cdc.gov/coronavirus/2019-ncov/need-extra -precautions/groups-at-higher-risk.html.

27. Li, L. Q., Huang, T., Wang, Y. Q., et al. (2020). Novel coronavirus patients' clinical characteristics, discharge rate, and fatality rate of meta-analysis. Journal of Medical Virology. https://doi. org/10.1002/jmv.25757

Publisher's Note Springer Nature remains neutral with regard to jurisdictional claims in published maps and institutional affiliations. 